\title{
Gul-i-Aftabparast (Helianthus annuus L.): An Under Exposed, Useful Flower of Unani Medicine Having Nutraceutical and Medicinal Properties
}

\section{Mohd Afsahul Kalam ${ }^{1 *}$, Afreen Habeeb², Arshia Noor ${ }^{2}$, Iqra Rifat ${ }^{2}$, Abdul Haseeb $^{2}$ and Shafiqur Rahman ${ }^{2}$}

${ }^{1}$ Research Officer Unani, Lecturer Department of Ilmul Advia, Regional Research Institute of Unani Medicine, Kashmir University, Habak, Naseembagh Campus,

Hazratbal Srinagar, J\&K, India

${ }^{2}$ PG Scholar, Department of Ilmul Advia, Regional Research Institute of Unani

Medicine, Kashmir University, Habak, Naseembagh Campus, Hazratbal Srinagar,

$J \& K$, India

*Corresponding Author: Mohd Afsahul Kalam, Research Officer Unani, Lecturer

Department of Ilmul Advia, Regional Research Institute of Unani Medicine, Kashmir

University, Habak, Naseembagh Campus, Hazratbal Srinagar, J\&K, India.
Received: May 22, 2021

Published: June 11, 2021

(C) All rights are reserved by Mohd Afsahul

Kalam., et al.

\begin{abstract}
Gul-e-Aftabparst (Helianthus annuus) is used as food and medicine worldwide. It is cultivated basically for its seeds, which give the world's second most important source of edible oil. It is a source of various chemical constituents which are used for the treatment of many fatal or life threatening diseases. Phytochemical analysis showed the presence of carbohydrates, phenolics, flavanoids, tannins, alkaloids, saponins, phytosterols, steroids, triterpenoids and fixed oils in the plant. In Unani System of Medicine its flowers are used medicinally, especially for brain and cardiac disorders. It possessed many pharmacological effects include anti-inflammatory, analgesic, anti-ulcer, central nervous system effects, hepatoprotective, and cardio-protective effects. This review highlights the chemical constituents and pharmacological effects of Helianthus annuus and its medicinal uses in the light of Unani Medicine.
\end{abstract}

Keywords: Azaryun; Helianthus annuus; Angina; Cardio-protective

\section{Introduction}

Nowadays, plants are used in nutraceuticals, cosmeceuticals and as medicinal hub for the treatment of various ailments. In Unani System of Medicine, various physicians have mentioned the medicinal uses of flowers, leaves, seeds, fruits etc. as medicine and added them in various formulations and dispense their own recipes; hence this requires documentation and maintenance. Surajmukhi (Helianthus annuus) is one among the most important medicinal flowers. Its Persian name Azarbun means the colour of fire with the resemblance of its flower, because it follows sun from east to west, it is called in Persian as Gul-i-Aftabparast (Gul=flower; Aftab=sun; Parast=to follow) [1]. The name sunflower may derived from the flower's head's shape, which resembles the sun, or from the false impression that the blooming plant appears to slowly turn its flower towards the sun as the latter moves across the sky on a daily basis [2]. Wild Helianthus annuus is a widely branched annual plant with many flower heads. The domestic sunflower, however, often possesses only a single large inflorescence (flower

Citation: Mohd Afsahul Kalam., et al. "Gul-i-Aftabparast (Helianthus annuus L.): An Under Exposed, Useful Flower of Unani Medicine Having Nutraceutical and Medicinal Properties". Acta Scientific Pharmaceutical Sciences 5.7 (2021): 117-123. 
head) atop an unbranched stem [3]. Leaves green, flowers golden yellow, heavy smelling with bitter and bad taste [1,2]. Sunflower is the world's third most important oil-producing crop, accounting for about $13 \%$ of the total world edible oil production [4]. Azaryun (sunflower) is the hub of medicinal values which is used as food and medicine worldwide. In Unani System of Medicine it is used for the treatment of various ailments like otorrhea, scrofula, infantile convulsion, diseases of brain and nerves, toothache, angina pectoris, rheumatism, hemorrhoids, jaundice, ascites, retention of urine, amenorrhea, sexual weakness, etc. and also used to remove toxins from the body, hence due to the presence of alkaloid, flavonoids, volatile oils and terpenoids essential. Various activities like antimicrobial, antitumor, anti-oxidant activities of the plant have been evaluated and several studies remaining.

Mutaradifat (vernacular names) [5,6]:

- Arabic: Azaryun, Hathwa; Duwwar al-Shams, Zohra al-Shams

- Bengali: Suriamukti, Surajmukhi [7]

- English: Sunflower, Lady Eleven O'clock, Marigold of Peru [7]

- French: Anthilion, Couronne de Soleil, Grand Soleil des jardins, Helianthe Soleil cultive, Soleil rigide, Tournesol [7]

- German: Sonnenblume

- Greek: Tilaun, Qiwatahna, [8] Heliotrpion [7], Matrawiqun;

- Gujrati: Surajmukhi [7]

- Hindi: Hurhuja, Surajmukhi [7]

- Italian: Clytia, Girasole, Harpalio [7]

- Japanese: Himawari

- Kashmiri: Gul-i-Aftab, Gul Akhtab

- Korean: Haebaragi

- Malayalam: Suryakandi [2]

- Marathi: Suryaphula, Surajmaka, Surajmaki, Suryakanta [7]

- Persian: Azargun, Gule Aftabparast [8]

- Portuguese: Girassol [7]

- Portuguese: Girasol, Heliotropio [7]

- Russian: Padsolnichnik [7]

- Sansikrit: Aditya Parni, Aditya Parnika [2]

- Spanish: Girasol, Mirasol [7]

- Swedish: Solros
- $\quad$ Tamil: Suryakanti [9]

- Telugu: Adityabhaktichettu, Poddatriguddachettu, Poddutriguddachettu [7]

- Urdu: Surajmukhi.

\section{Botanical description}

Helianthus annuus L. is a coarse, stout and erect annual plant. Stem 1 - 2 meters high, round, hispid, branched, each terminating with capitulum (composite head). Leaves alternate; broadly ovate, 7 - $30 \mathrm{~cm}$. long, or smaller above, with slightly acuminate at the apex, coarsely toothed, lower leaves cordate at the base and upper cuneate. Inflorescence: Large, composite heads, solitary at terminal end of peduncle or terminal on a branch, or axillary; composite disk usually 2 - $8 \mathrm{~cm}$ wide or more including rays; peduncles 2 - $20 \mathrm{~cm}$ long, densely hispid-scabrous. Receptacle low-convex and chaffy. Flowers: The outer flowers, which resemble petals, are known as ray flowers, they are sterile, 1.5 - $4 \mathrm{~cm}$ long, ligules yellow, $2.5-5 \mathrm{~cm}$. long. The flowers in the center of the head are called disk flowers. Disc flowers flat, $3-5 \mathrm{~cm}$ broad, perfect, corolla lobes 5 - $8 \mathrm{~mm}$ long, purple-brown to yellow arranged spirally, tubular, each floret subtended by a small firm, paleaceous bract attached to the receptacle, often 3 - toothed. Pappus 2 readily deciduous, awnlike palea floret subtended by a small firm, paleaceous $2-3.5 \mathrm{~mm}$ long. These flower heads mature into fruit $[7,10,11]$. Roots: Initially tap rooted, when matured, developed large fibrous, lateral roots. All parts are often much larger in cultivated forms [7]. Gynoecium: Ovary inferior. Fruit: Achenes 3-6 mm long or more, narrowly obovate to ovate, more or less 4 angled, somewhat compressed, glabrous to minutely puberulent especially at apex, gray to brown and occasionally mottled to striped [12-14].

Taxonomical classification [15]

Kingdom: Plantae

Division: Angiospermae

Subdivision: Eudicots

Class: Asterids

Order: Asterales

Family: Asteraceae

Subfamily: Helianthoideae

Synonyms: Chrysanthemum peruvianum, 


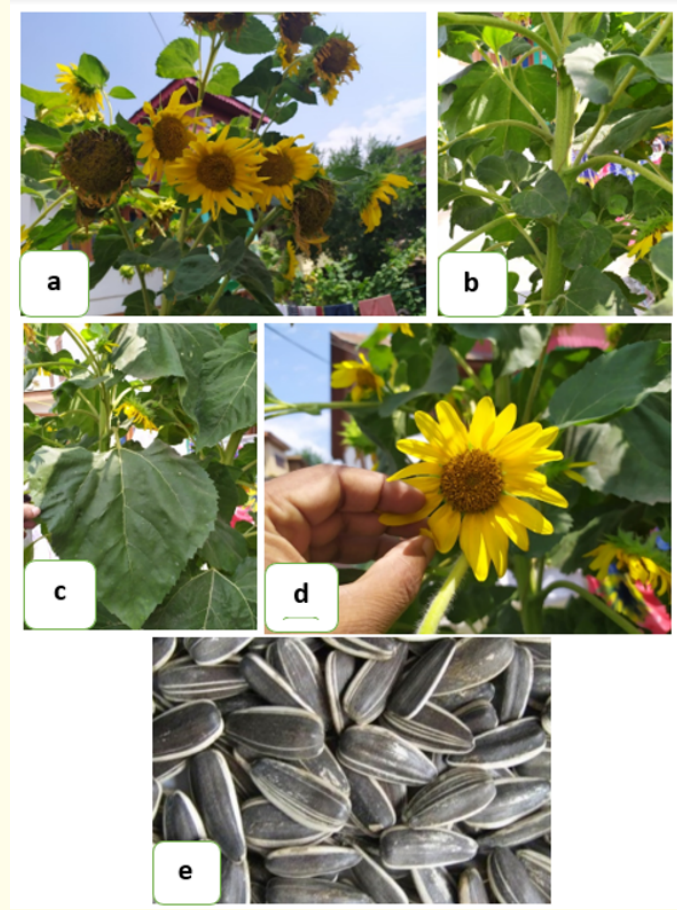

Figure 1: Showing a) flowers on the top; b) stem with leaves; c) single leaf; d) single flower and e) seeds.

Helianthus annuus subsp. jaegeri,

Helianthus annuus var. lenticularis,

Helianthus annuus var. macrocarpus,

Helianthus annuus var. texanus,

Helianthus aridus,

Helianthus lenticularis [16].

Ja-e-waqu'a (distribution)

It is native to United States, Mexico and Canada and now widely cultivated in countries of both tropical and temperate [5], it is also cultivated in India.

Ajza-e-musta'mala (parts used)

Flowers, leaves and roots.

Mizaj (temperament)

Hot and dry in $3^{\text {rd }}$ degree [1]; some considered it in $2^{\text {nd }}$ degree.

\section{Af'al (action)}

Its flower has Tiryaq (antidote), Muhallil (resolvent), Jali (detergent), Muqawwi-i-Qalb (cardiac tonic), Mufarrih Qalb (exhilarant), Mufattih Sudad-i-Dimāgh (brain deobstruent), Munaqqi-i-Dimāgh (evacuant of vitiated humour from brain), Mufattih Sudad-i-Jigar (liver deobstruent), Muqawwi-i-Jigar (hepatotonic), Muqawwi-iMi'da (stomachic), Muqawwi-i-Bāh (aphrodisiac), Mufattit-i-Hasāh (lithotriptic), Mudirr-i-Bawl (diuretic), Mudirr-i-Hayd (emmenagogue), Mufattit-i-Hasah (lithotryptic) [1].

Iste'malat (uses)

Flowers are used in Umm al-Ṣibiyān (infantile convulsion), Amrād-i-'Așbiyya Barida (diseases of brain and nerves cold), Waj' alAsnan (toothache), Waj' al-Qalb (angina pectoris), Waja' al-Mafāsil (rheumatism), Bawāseer (hemorrhoids), Yaraqān (jaundice), Istisqa (ascites), Iḥtibās-i-Bawl (retention of urine), Iḥtibāth-i-Hayd (amenorrhea), Du'f-i-Bāh (sexual weakness), Qulanj (colitis), Kalaf (melasma), Zakhm Reya (ulcer of lungs), Shiqāq-i-Miq'd (anal fissure), Khanāzir (scrofula) and also used to remove toxins from the body $[1,17]$. Seeds-build up physical endurance and resistance against diseases; a decoction is used in coughs and colds, bronchial, laryngeal and pulmonary affections, whooping cough, also as a febrifuge and diuretic.

\section{Tarkeeb Iste'mal (Method of administration)}

In the literature of Unani Medicine Azaryun (Helianthus annuus L.) is mentioned as food and medicinal source for the treatment of different disease. It is utilized for several actions like speedy wound healing activity, as kidney stone repellant, for treating chest pains and pulmonary troubles, to alleviate Waj' al-Mafāsil (rheumatism), Irqun Nasa (sciatica), Daus Salab (alopecia), Du'f A'sab (nerve weakness), Waj 'al-Athnan (toothache) etc. for this purpose various parts of the plant is used in various forms like, powder tea, decoction, plaster, poultice etc. the method of its administration according to Unani physicians is as follows.

\section{Amrād-i-A'sab wa Dimāgh (diseases of nerve and brain)}

Decoction of its root poured into nostril, removes morbid matter from the brain [8] 14 gm juice of fresh leaves is taken with warm water, cures brain disorders by removing Fudlat-i-Dimāgh, and its extract is also taken as Sa'ut for the same purpose. 
Amrād-i-Anf, Uzn wa Halaq (Diseases of ENT)

$10 \mathrm{ml}$ leaves juice cooked with linseed oil $25 \mathrm{ml}$ is used to pour in the ear to cure otorrhea [2].

Amrād-i-Dandan, Liththa wa Gardan (Diseases of Gum, teeth and neck)

A mouthwash and Sa'ut (nasal drop) of the root extract is effective for Waj' al-Asnān which occurs due to cold [1] The necklace of its root on the neck is applied to cure Kanthmala (scrofula) [8].

\section{Amrād-i-Qalb (Cardiac diseases)}

Its flowers in the quantity of $3 \frac{1 / 2}{2}$ gm is very effective for the patients having cardiac diseases of cold temperament, but in hot temperament persons, it produces stimulation. A Dimad (paste) of its flower applied locally to cure chronic cardalgia [1].

Amrād-i-Nizām-i-Hadm, Jigar and Tihāl (Digestive disorders, liver and spleen)

If a liniment of its flower applied locally, it resolves the ulcer of stomach, liver and spleen. The decoction of its flower and leaves is used for emesis.

Application of its flowers and leaves on anus, after pulverizing in Roghan (oil) has benefits in Bawasir. $2 \mathrm{~g}$ powder of its seeds is taken to remove helminthes from the intestines [2].

Amrād-i-Nizām-i-Bawl wa Tanāsul (Diseases of Urogenital organs)

A paste of flower is locally applied on lower back to strengthen the sexual organ and to improve the sexual power $[1,8]$. A pessary made from its root is applied as abortifacient [1]. It helps in conception when a women used its pessary in vagina [8].

\section{Amrād-i-Mafāsil wa Uzzām (Musculoskeletal and joint pain)}

Its ash applied with vinegar as epithem is useful in sciatica $[18,19]$. A paste of its flower is applied to cure waj' al-Mafāșil, Waj' al-Zuhr [1], Irqun Nasa (sciatica), Niqris (gout) etc.

\section{Amrād-i-Jild wa Sha'r (skin and hair diseases)}

When applied after pulverizing with vinegar it is useful in Da' al-Thālab (alopecia) [18,19] It gives good result, when applied on Kalaf after pulverizing with vinegar [17].
Ilaj-i-Samum wa Tahffuz-i-Amrād (treatment of poisoning and prevention of diseases)

It is useful against all poisons, especially in poisoning by animal bites $[18,19]$. Its flower is a good fly repellant. Its fumigation is also used to remove lizard and rats from the homes [8].

Awarām, Buthur and Quruh (Inflammations, abscesses wound and ulcers)

Flowers are applied locally with Roghan to resolve Awaram-iSalaba. The ash of its leaves is applied with vinegar to cure wound.

\section{Mazarrat (Toxicity)}

Musaqqit-i-Janīn, causes stimulation in hot tempered, contraindicated in hot temperament persons and harmful for spleen [1]. According to Dioscorides, if a pregnant women touches its wild variety or uses it as pessary, she immediately will have abortion [19] The LD50 of the ethanol extract of leaves of Helianthus annuus L. was found to be $14 \mathrm{~g} / \mathrm{kg}$ in rats [20].

\section{Musleh (Corrective)}

Sikanjabeen and pure honey is used as corrective [1].

\section{Badal (Substitute)}

Salikha (Cinnamomum tamala) $1 \frac{1}{2}$ part and Zafran (Crocus sativus) $4^{\text {th }}$ part is used as substitute [1], and some says Babuna (Matricaria chamomila) and Badaward (Fagonia arabica) may be used as substitute.

\section{Miqdar khurak (Dose)}

18 gm (flowers, leaves and root juice); $4 \frac{1 / 2}{2}-7$ gm (head of the flower).

\section{Murakkabat (Compound formulations)}

Various Kushta like Kaushta chandi, Kushta sona and Kushta shingarf are prepared in the juice of Surajmukhi and a formulation named Gulqand Surajmukhi is also prepared by its flower in addition with Honey [2].

\section{Scientific studies}

\section{Chemical constituents}

Phytochemical analysis showed that Helianthus annuus contained carbohydrates, phenolics, flavanoids, tannins, alkaloids, saponins, phytosterols, steroids, triterpenoids and fixed oils. Fatty ac- 
ids identified in sunflower oil include, palmitic, palmitoleic, stearic, oleic, linoleic, alpha linoleic, gamma linoleic, arachidic, gadoleic, tetracosanoic, and behenic acid [21]. The oil also contains tocopherols (alpha-type 92\% of the total) and phytosterol (betasitosterol $154 \mathrm{mcg} / 100 \mathrm{~g}$ ) [9]. It contains more of the antioxidant vitamin $\mathrm{E}$ than any other vegetable oil and is also high in vitamins A and D.

\section{Pharmacological studies}

Various studies had been done by researchers to investigate the pharmacological activities associated with Helianthus annuus L. are as follows:

- Anti-inflammatory effect: The anti-inflammatory effect of helianthoside compounds isolated from n-butanol-soluble fraction of a methanol extract of sunflower was studied against 12-0-tetradecanoylphorbol-13-acetate [TPA] induced inflammation [1.7 nmol/ear] in mice, all of the compounds tested exhibited marked anti-inflammatory activity, with $\mathrm{ID}_{50}$ values in the range $65-262 \mathrm{nmol} /$ ear [22].

- Hepatoprotective effect: The hepatoprotective activity of ethanolic and aqueous extracts of Helianthus annuus L. flowers was studied in CCl4 induced hepatotoxicity in Wistar rats. Treatment with the Helianthus annuus L. flower extracts significantly $[\mathrm{P}<0.001]$ reduced elevated serum enzymatic level of serum glutamate oxaloacetate transaminase, serum glutamate pyruvate transaminase, alkaline phosphatase and total bilirubin in $\mathrm{CCl} 4$ induced rats treated with $200 \mathrm{mg} / \mathrm{kg}$ bw. The biochemical effects of the ethanolic and aqueous extracts of Helianthus annuus L. flowers were further confirmed by histopathological examinations of liver [23].

- Anti-asthmatic activity: In a study, Heo., et al. (2008) examined the effects of the aqueous extract of Helianthus annuus L. seed on an in vivo anti-asthmatic model on ovalbumin induced mice and their lungs were assessed by hematoxylin and eosin staining. These findings collectively suggests that the extract has considerable potential in reducing the asthma [24].

- Nephroprotective effect: The effect of aqueous and ethanolic extracts [500 mg for each for 10 days] of Helianthus annuus L. leaves on calcium oxalate nephrolithiasis was studied in male rats. Ethylene glycol and Ammonium chloride feeding resulted in hyperoxaluria as well as increased renal excretion of calcium and phosphorus. The increased deposi- tion of stone forming constituents in the kidneys of calculogenic rats was significantly lowered by treatment with aqueous and ethanolic extracts [25].

- Antitumor and antioxidant: Abushama., et al. (2014) recently at Sudan National Research Center investigated the antitumor and antioxidant activity of fixed oil of Sudanese medicinal plants including Helianthus annuus L. Antioxidant activity results of the five fixed oils measured using DPPH and fixed oil of Helianthus annuus L. showed moderate antioxidant activity. Fixed oil of this plant showed no activity when using Iron Chelating Assay [6].

- Reproductive effects: The effects of ethanol extract of leaves of Helianthus annuus [0.5 g/kg of orally for 2 weeks] on the fecundity was studied in rats. The results showed that coital frequency was unaffected by the extract treatment but pregnancy rate and number of pups per rat and per group were reduced significantly. The histo-degenerative changes induced by the ethanol extract in the gonads may be responsible for the reduced fecundity observed in treated adult rats [26].

In studying the effects of the ethanol extract of the leaves of $\mathrm{He}$ lianthus annuus on the histology of the testes, blood level of some reproductive hormones and epididymal sperm properties in Wistar rats, it appeared that the extract possessed some anti-fertility effects [27].

\section{Effects on central nervous system}

The methanolic extract of Helianthus annuus L. seeds was evaluated for central nervous system activity in mice model. The results revealed that the methanol extract of Helianthus annuus L. seeds at dose of 100 and $200 \mathrm{mg} / \mathrm{kg}$ caused a significant increase in the spontaneous activity. On $200 \mathrm{mg} / \mathrm{kg}$ dose it showed significant increase in grip strength and pain responses and also showed strong movement response in spontaneous activity, pinna reflex and touch response with moderate increase in awareness and alertness. It also showed moderate anxiolytic activity [light-dark box and elevated plus maze test]. In respect of latency of entry into the light box and number of entries, Helianthus annuus L. showed moderately significant anxiolytic effect at the dose of both $100 \mathrm{mg} / \mathrm{kg}$ and $200 \mathrm{mg} / \mathrm{kg}$ both. The methanolic extract of Helianthus annuus $\mathrm{L}$. seeds also caused remarkable antidepressant activity [tail suspension test]. Helianthus annuus L. showed significant antidepressant 
activity $[\mathrm{P}<0.05]$ by decreasing the immobility time as compared with imipramine induced and control group [28].

\section{Anti-obesity activity}

The anti-obesity activity of the methanolic extract of Helianthus annuus L. seeds was studied in mice model. The mice received cafeteria diet, atorvastatin [10 mg/kg] and Helianthus annuus L. 200 $\mathrm{mg} / \mathrm{kg}$ daily for 6 weeks. Parameters such as food consumption, locomotor activity, body weight, body mass index (BMI), lee index of obesity (LIO), total cholesterol, triglyceride, LDL, HDL and glucose were studied. The methanolic extract of Helianthus annuus L. seeds significantly increased locomotor activity (rearing, grooming, ambulation) with HDL and significantly decrease food consumption, body weight, BMI, LIO, total cholesterol, triglyceride, LDL and glucose [29]. Extracted oil from dehulled seeds (chlorogenic acid, present in hulls, interferes with lipid metabolism) reduced serum and hepatic cholesterol in healthy women.

\section{Cardio-protective effect}

The protective effect of oil of Helianthus annuus L. on myocardial infarction induced by epinephrine in New Zealand rabbits was determined. Helianthus annuus L. oil at doses of $20 \mathrm{mg} / \mathrm{kg}$ has protective effect on myocardial infarction induced by epinephrine in New Zealand rabbits [30].

\section{Conclusion}

Azaryun (sunflower) is the hub of medicinal and nutritional values which is used as food and medicine worldwide. It has various alkaloid, flavonoids, volatile oils and terpenoids essential hence various activities like antimicrobial activity, antitumor activity, anti-oxidant activity etc. have been evaluated. It may direct the further research on Azaryun (Helianthus annuus L.) for some more hidden activities for which it is used in Unani System of Medicine.

\section{Acknowledgement}

Authors are highly thankful to the Assistant Director In charge and Librarian, RRIUM, Srinagar for providing facilities in the library for reviewing literature regarding the topic. I have also thankful to all the editors and authors of the books from where the material for this paper was consulted, discussed and used herein.

\section{Bibliography}

1. Abdul Hakim. "Bustanul Mufaradat". New Delhi: Idara Kitabus Shifa (2011): 205.
2. Abdullah Hakim and Sharma KKD. Hind Pak ki Jadi Bootiyan. Maktaba Daniyal, Lahore, YNM, 165, 66.

3. Bastas K., et al. "Helianthus annuus (sun flower)". Plant Disease 93.12 (2009): 1352.

4. Potrykus I. "Gene transfer to cereals: an assessment". Biotechnology 8 (1990): 535-542.

5. U.S. National Plant Germplasm System, Taxon: Helianthus annuus $\mathrm{L}$.

6. Abushama MF., et al. "Lethality and Antioxidant Activity of Some Sudanese Medicinal Plants' Fixed Oils". European Journal of Medicinal Plants 4.5 (2014): 563-570.

7. Kirtikar KR and Basu BD. Indian Medicinal Plants, Volume II, 2nd edition. Delhi: Periodic Expert Agency 1370 (2012): 1371.

8. Ibn Baitar. Al-Jami Li Mufradatul Advia wal Aghzia. New Delhi: Central Council for Research in Unani Medicine 31 (1985): 32.

9. Khare CP. "Indian Medicinal Plants: An illustrated Dictionary". New Delhi: Springer pvt. Ltd. (2007): 304.

10. Leung J., et al. "Phenolic components of sunflower flour". Journal of Food Science 46.5 (1981): 1386-1388.

11. Marinković R. "Path-coeficient analysis of some yield components of sunflower (Helianthus annuus L.)". Euphytica 60.3 (1992): 201-205.

12. Heiser CB. "The sunflower". 1st edition. Oklahoma Press (1976).

13. Schilling EE and Heiser CB. "Infrageneric Classification of Helianthus (Compositae)". Taxon 30.2 (1981): 393-403.

14. Halvorson WL. Helianthus Annuus L. U.S. Geological Survey/ Southwest Biological Science Center (2003): 1-26.

15. Saini S and Sharma S. "Helianthus Annuus (Asteraceae): A Review". International Journal of Pharma Professional's Research 2.4 (2011): 465-470.

16. Lim TK. "Helianthus Annuus". Edible Medicinal and Non-Medicinal Plants 7 (2014): 372-396.

17. Khan Azam. Muheet-i-Azam (Urdu Trans:). New Delhi: Central Council for Research in Unani Medicine (2012): 183-184. 
18. Ibn Sina. Al-Qanun Fil Tib. Tibb-i-Unani Ka Encyclopaedia. New Delhi: Aijaz Publishing House (2010): 276.

19. Ibn Hubal Baghdadi. Kitabul Mukhtarat Fil Tib, Vol-2. New Delhi: Central Council for Research in Unani Medicine (2005): 54.

20. Suo M and Yang J. "Ceramides isolated from Helianthus annuus L". Helvetica Chimica Acta 97.3 (2014): 355-360.

21. Etievant PX., et al. "Isolation and identification of volatile constituents of sunflowers (Helianthus annuus L.)". Journal of Agricultural and Food Chemistry 32 (1984): 503-509.

22. Ukiya M., et al. "Triterpene glycosides from the flower petals of sunflower (Helianthus annuus L.) and their anti-inflammatory activity". Journal of Natural Products 70.5 (2007): 813-816.

23. Vasavi AKE., et al. "Evaluation of hepatoprotective and antioxidant activity of Helianthus annus flowers against carbon tetrachloride [CCl4] induced toxicity". International Journal of Pharmacology and Toxicology 4.2 (2014): 132-137.

24. Heo JC., et al. "Aqueous Extract of The Helianthus annuus Seed Alleviates Asthmatic Symptoms In Vivo". International Journal of Molecular Medicine 21.1 (2008): 57-61.

25. Khan NI., et al. "Antilithiatic effect of Helianthus annuus Linn leaf extract in ethylene glycol and ammonium chloride induced nephrolithiasis". International Journal of Pharmacy and Pharmaceutical Sciences 2.4 (2010): 180-184.

26. Emamuzo ED., et al. "Effects of ethanol extract of leaves of Helianthus annus on the fecundity of Wistar rats". Asian Pacific Journal of Tropical Medicine 3.6 (2010): 435438.

27. Ejebe DE., et al. "Effects of ethanol extract of leaves of Helianthus annuus [common sunflower] on the reproductive system of male Wistar rats: testicular histology, epididymal sperm properties and blood levels of reproductive hormones". Biomedical and Pharmacology Journal 1.1 (2008): 65-78.

28. Islam RT., et al. "In vivo anti-obesity activity of methanolic extract of Helianthus annuus seeds". International Journal of Applied Research 1.13 (2015): 518-522.

29. Islam RT., et al. "Central nervous system activity of the methanol extracts of Helianthus annus seeds in mice model". International Current Pharmaceutical Journal 5.1 (2015): 1-4.
30. Guardia-Espinoza E., et al. Revista Peruana de Medicina Experimental y Salud Pública 32.1 (2015): 80-86.

Volume 5 Issue 7 July 2021

(C) All rights are reserved by Mohd Afsahul Kalam., et al. 